\title{
INTERNATIONAL EXPANSION OPPORTUNITIES FOR MULTI-LEVEL MARKETING VIA PERSONAL NETWORKS: AN ETHNOGRAPHIC STUDY FROM COLOMBIA
}

\author{
William Franco \\ Universidad EAFIT \\ Maria Alejandra Gonzalez-Perez \\ Universidad EAFIT
}

\begin{abstract}
Although multi-level marketing (MLM) and direct sales companies have risen controversies and ethical concerns in recent years, MLM has rapidly expanded to developing and emerging markets in the last decades. Companies like Yanbal, Amway and Oriflame, are some of the multinationals that have internationalized in the Latin America and the Caribbean. Through a grounded theory approach, and using Colombia as a sample of a Latin American country, the internationalization of these companies was analyzed. A vast amount of the data collection for this study was gathered through an ethnographic immersion, and through participant observation, the activities and recruiting practices of these firms was analyzed to determine if they provided international income opportunities in the bottom of the pyramid (BOP) markets. The ethnographic research found that several multi-level and direct sales companies provide international income opportunities, but do not contribute to the increase of formal jobs creation. The results of this study contribute to the existing literature on multi-level marketing and direct retailing firms and the study provides insights about the internationalization of the MLM companies operating in countries with a predominant population at the BOP through personal networks.
\end{abstract}

Keywords: Internationalization; Multi-level Marketing; Direct Sales; BOP; Latin America; Business Networks.

"This business opportunity is for those who want to succeed as independent entrepreneurs and not worry wondering if you are going to be employed or not in the future. Not having to wonder what are you going to do to survive another month because your salary is not enough" (Amway Host, 2014).

\section{INTRODUCTION}

Although, the business model of multi-level marketing (MLM) was created in 1945 (Bosley \& McKaege, 2015), MLM and direct sales companies have risen controversies in recent times (Feinberg \& Eastick, 1997; Peterson \& Albaum, 2007); however, the sales of multilevel marketing (MLM) and direct retailing companies in Latin American and the Caribbean

2 Corresponding author: Department of Management, Business School, Universidad EAFIT Carrera 49 N ${ }^{\circ} 7$ Sur - 50, B1. 26-416 Medellin, Colombia. Email: mgonza40@eafit.edu.co 
(LAC) countries has experienced significant growth in past years (WFDSA, 2012, 2013), and is expected to experience a 4\% constant compound annual growth until 2018 (Euromonitor International, 2014b). Amway and Avon are popular United States based multinationals in the MLM industry that have grown and consolidated in the Latin American markets. Yanbal (Peruvian) and Natura (Brazilian), both Latin American MLM companies in the cosmetics and personal care industry, have also emerged and conquered markets in their own region. The latter mentioned are major participants in their industry. According to Euromonitor International (2014) Latin America has been a market revolution of expectations in beauty and cosmetics.

MLM companies, have no barriers to expand their selling network as they accept independent and casual consultants regardless of education level, work availability, age, experience, socio-economic status, or gender (Albaum \& Peterson, 2011; Bloch, 1996; Choudhary \& Kamal, 2013; Croft \& Woodruffe, 1996; Nga \& Mun, 2011). Therefore, these companies can provide an income opportunity to those who are currently outside the labor market, aim for complementary income opportunities, or are seeking entrepreneurial freedom. According to Gordan (2010), "Colombia mirrors solid beauty industry growth seen elsewhere in Latin America". The country has is reaching a ceiling of sales and penetration of the direct selling business model, even at clients at the bottom of the pyramid, which has become more aspirational with a better economic landscape (Euromonitor International, 2015b; Mason et al, 2013). With this information in context, and using Colombia as model representing a Latin American country, reason why this country was chosen as the context of the study, this research aims to provide a deep analysis of the latent internationalization of the selling and consuming system of multi-level marketing multinationals in LAC by targeting the bottom of pyramid by providing promising income (and consumption) opportunities to its network. Also, it intends to explore if the distributors (independent agents, associates, etc.) may obtain an international income opportunity from these firms. Lastly, this research aims to explore if the internationalization of MLM companies in Latin America might increase self-employment in countries with a large proportion of citizens at the BOP.

In order to design and to conduct this study, an academic literature was conducted on the relationship between multi-level, direct selling (due to its ties with MLM companies) and selfinitiated expatriation took place. Then, a grounded theory approached process for both data collection and data analysis was carried out through an ethnographic immersion, and it was complemented with data collected and systematized from secondary sources, such as corporate reports and specialized business media. The study was developed in Colombia due to the proximity of the researchers to the country. Additionally, Colombia is an emerging economy country (Bremmer, 2015) which can serve as a representation for other Latin American and Caribbean countries (Gonzalez-Perez \& Velez-Ocampo, 2014). Most importantly, Colombia holds the twelfth position worldwide in MLM revenue and is on the top 10 worldwide list of MLM highest percent growth (Tortora, 2014). The chosen companies for the study are Yanbal (Peru), Amway (United States) and Oriflame (Sweden). These companies were selected on the basis of their popularity at the time in Colombia and that all three were on the top 15 best MLM's in Latin America, with Amway holding the first place (Castrejon, 2014). Lastly, results and limitations from this research are presented and it is made evident a significant contribution to the International Business field by expanding the under rigorously researched understanding of MLM, and also by providing lights in their process of international expansion. 
The remainder of paper is structured as follows:

Section 2 discusses the previous literature related to international expansion of MLM based on personal networks. The adopted methodological approach is offered on section 3. In this section, a description of the studied sector and the sample characteristics is presented; furthermore, the methodological considerations for this paper based on ground theory approach. Section 4, summarizes the main findings of the present study, and discusses the results, and finally section 5 provides final conclusions of this study offering a contribution to the understanding of international expansion of MLM.

\section{LITERATURE REVIEW}

This literature review presents and discusses previous works in multi-level marketing (MLM) and their international expansion through personal networks.

MLM is a type of compensation structure, and it can be defined as a form of direct selling and a distribution method where distributors are non-salaried, can earn income from their sales of a product or service and can also generate a percentage of the sales executed by the people they recruit for the company (Peterson \& Albaum, 2007; Vander \& Keep, 2002). Furthermore, the distributors are commonly independent contractors that distribute their products and recruit new members through non-traditional channels, such as door-to-door sales, sales appointments and product parties (idem). Hence, this type of activities reduces the involvement of the retail store, reducing distribution costs for the multi-level firms. The distribution and growth of these networks also heavily rely on peer relationships (Albaum \& Peterson, 2011; Bloch, 1996; Choudhary \& Kamal, 2013; Croft \& Woodruffe, 1996; Lahiri \& Das, 2012; Nga \& Mun, 2011). There are different studies describing the importance of peer influence in the international growth of a firm (Henkel \& Block, 2013). Given that this industry heavily relies on recruiting, their business activities constantly comes under questioning as they are blamed of conducting pyramid schemes (Feinberg \& Eastick, 1997). Some studies (Koehn, 2001; Peterson \& Albaum, 2007) have differentiated and discuss the ethical issues between pyramid schemes and MLM. In pyramid schemes, a member makes an investment to receive authorization to recruit others and collect a commission when those recruit others to join the scheme. While legitimate MLMs must monitor their independent distributors to make sure that they are conducting retail sales and charge low entry fees to market their products (Koehn, 2001).

Considering that MLM, or network marketing as it is also known, the growth of these companies usually depend on family ties (Croft \& Woodruffe, 1999; Dai et al, 2011; Hill et al, 2006; Pratt \& Rosa, 2003; and Volinsky, 2006). Pratt and Rosa (2003) found in their analysis of 3 network marketing companies, including Amway, that these companies placed a high importance in the non-work lives of its members. Also, these companies encourage their distributors to recruit others from their social and family networks. Thus, they encourage members to bring their family into the business physically or psychologically. In the same manner, the companies build a system of family by developing family like bonds between current distributors and new members (Pratt and Rosa, 2003). When companies like Amway reach markets, one of 
their methods of expansion is their effective recruiting and retention techniques. Pratt (2000) conducted an ethnographic interview of Amway distributors and he found that members were instilled an identification with the company through "sensebraking" and "sensegiving" practices. Members first went through a face where the organization changed their perspective of them, then proceeded to create an identity within the company (Pratt, 2000). Additionally, MLM's usually require their new members to become their first customers, building a customer base before creating a distribution channel. Hill, Foster and Volinsky (2006) explained that network marketing can be very beneficial to firms as they can help pick up the potential customers that fell through the cracks. Through the use of statistical data, Hill et. al. (2006) analyzes network marketing and how consumers contribute to the adaption of a service. This literature helps the internationalization case of many MLM companies by showing that customer-to-customer relations can be very efficient at expansion because the consumers at some point become the sellers of the same products they are consuming. These consumers may become independent sellers for these companies because of their attractive compensation plans and profits. Profits are made through the sales made by the seller or by the sales generated by those whom they recruited. All the companies have different compensation plans and "compensation plan structure can have a profound effect on how distributors' time is spent, and therefore plays a critical role in the company's overall growth and success through time" (Coughlan \& Grayson, 1998). Also, Croft and Woodruffe (1996) studied the international network of MLM between the United States and Japan, and found than in certain specific cases (when there are strong social or family bounds) network marketing channel could be more effective. Furthermore, Dai et al (2011) found that many Chinese immigrant in western countries began entrepreneurial activities by joining major MLM networks at their host countries.

Business analysts have noticed that contrary to regular businesses, multi-level marketing companies' success run counter to economic cycles. These firms usually have their success in countries that had just experienced an economic crisis (Cahn, 2008). In a study conducted in Mexico, during the economic changes of the 1980s towards a more capitalistic market, multi-level marketing companies entered the market experiencing success as the citizens were looking to live under the new neoliberal model instead of the old social welfare system (Cahn, 2008). Masi de Casanova (2011b), conducts an ethnographic study like Cahn (2008) and analyzes direct selling and multi-level marketing in Latin America, focusing hers in Ecuador. Her research involved several interviews and experiencing the lives of women involved in direct sales working for Yanbal, a leading cosmetics multi-level marketing firm from Peru.

The economic turn that Cahn (2008) discussed in his research in Mexico that led to the growth of multi-level marketing companies, was also witnessed in Thailand by Wilson (1999). In her study, she makes a connection between these types of companies and the informal economy without mentioning the informal sector per se. Cahn (2008) states that after the 1997 financial crisis in Thailand, Thai newspapers were promoting direct sales and multi-level marketing companies as an alternative to complement their salaries and in some cases people used it as a source of income to avoid being unemployed. The highlight of this business is that it provides income opportunities to low-skilled workers making it attractive to working and low-middle class members (Wilson, 1999). Nga and Mun (2011), witnessed the growth of 
multi-level marketing companies in Malaysia, another emerging market country. Like Vander et al. (2002), the authors begin by differentiating MLM with pyramid schemes. Since wages are decreasing and unemployment is rising in the country, the authors conducted a study to analyze perception of MLM in Malaysia by the young future university graduates and on their willingness to take up MLM as a career. The study found that the youth in Malaysia were willing to take MLM as a permanent career option or to supplement their income (Nga et al., 2011).

Companies like Amway and Avon have found significant success in internationalizing in emerging and developing economies. It is important to understand the internationalization strategies that firms may use to expand to foreign markets. Cuervo-Cazurra (2011) analyzed the selection process as to which country a starts their internationalization process. In the article he describes sequential internationalization as where companies choose countries with a psychic distance close to the firm's country of origin to internationalize. Furthermore, Cuervo-Cazurra (2011) mentioned that firms required three types of knowledge to internationalize: knowledge of complex operations for the overall foreign expansion; knowledge about foreign operations and customers; and knowledge about norms and values in foreign countries. This may have been the case for these companies to internationalize in the beginning stages; however, they probably gained significant experience in their international operations to expand to other countries not based on psychic distance but based on other opportunities to capture new markets. The Uppsala internationalization model also contemplated a pattern where the firm would frequently start international operations in a market that was close, in psychic distance, to the one of the home market to later enter markets more distant (Johanson \& Vahlne, 2009). Notwithstanding, Johanson \& Vahlne (2009) revisited the model because they saw the need to consider business networks in their model. These networks, if established beforehand, are key to the internationalization process (Coviello, 2006). One of MLMs most crucial components is their network of future sales staff (independent consultants), with whom the company will hold a close tie to. This is important as it is key to have a corresponding relationship between both parties to experience a successful internationalization (Johanson \& Vahlne, 2009). The business network and level of commitment between both parties determines the level relationship profitability as a result; hence, a high level of trust is needed in order to successfully rely on each other (Holm, Eriksson \& Johanson, 1996). Holm et. al. (1999) would later stress the need of these business networks at an international level to add value to business operations. The business network and relationship is crucial between the MLM and its independent distributor, but given that relationships are socially constructed, Vasilchenko \& Morrish (2011) state that these networks may later develop into greater business collaborations and exploitation of opportunities to enter foreign markets. Liesch, Welch \& Buckley (2011), identified in their research that risk can be higher in the presence of international exposure; hence, these networks may be useful in the process of expanding the MLM business operations in the international arena.

This study focuses on how MLM companies internationalize in emerging. Many people of the informal economy cannot find formal employment due to barriers to entry. Many of the members found at MLM events are older people, which in a country like Colombia, are not commonly considered for formal employment. Stereotypes due to age, disabilities, and 
disadvantages in relevant work skills, especially when competing for jobs with the young, are barriers to generate income for the aging workforce (Anderson, Fields, Harootyan \& Richardson, 2013). Women have also faced barriers to employment, and in nations who have progressed and strived to provide better opportunities, they have faced disadvantages in the work place. In many cases women are not treated equally and are not compensated equally to their male counterparts (Markovic, 2009). Draper (1985) discussed women's work in the process of development in Latin America and she discusses the fact that two major types of labor activities for women are domestic work and informal labor. Many women take on informal jobs to make a living while in the process of transitioning to the formal sector (Draper, 1985). In a study conducted in South Africa, Avon experience significant success by providing opportunities to impoverished women and giving them an opportunity to earn a better living (Scott, Dolan, Johnstone-Louis, Sugden, \& Wu, 2012). For this reason, multi-level marketing companies can internationalize through networks in the informal economy in Latin America, by providing income opportunities.

Based on the reviewed literature, it was noticed that research has been conducted in regards to multi-level marketing and companies that run their distribution through this method of expansion. However, there is a gap in literature in regards as to how MLM and opportunities to work abroad via MLM and personal networks. For this reason, this paper could be a contribution to the current business literature on how the MLM companies internationally expand and if the distributors can obtain an international income opportunity from these firms.

\section{RESEARCH METHODOLOGY}

This study is based on a modified ground theory approach (Strauss \& Corbin, 1994; Strauss \& Corbin, 1998) involved a systematic process of data collection and data analysis, and furthermore a permanent comparative analysis. The original Strauss \& Corbin (1994) approach was modified in the sense that this study was designed and structured based on preconceived theoretical approaches on MLM international expansion (as it was presented at the literature review section).

As mentioned, the research method of this study is a modified ground theory approach. It included exploratory qualitative research that involved collection and analysis of primary and secondary sources, and most importantly, an ethnographic study that involved participant observation. Doz (2011) discussed the fact that most research international business has been through the use quantitative methods and why qualitative methods have been scarce. In an effort to understand the involvement of ethnographic studies in qualitative research methods, Iacono, Brown and Holtham (2009) provided insights in regards to the benefits, limitations and how to handle the challenges that arise from participant observation. Iacono et al. (2009) first discussed the origins of ethnographic research that derived from social sciences, more specifically in anthropological studies. In these cases, researchers would travel to foreign lands to integrate themselves in their societies and immerge themselves in their culture to record at firsthand what was being observed (Iacono et al., 2009). Hence, based on this, it was determined that for this study a grounded theory approached with an emphasis on ethnographic methods was appropriate as it would allow penetrating the culture 
of the companies (and individual sellers) to see firsthand its practices and values and witness from a participant standpoint. Furthermore, this method was found necessary since there is limited reliable information available about the activities of these companies. Observing as a participant provided reliable information about the company's practices and the opportunity to record participant experiences. That is the important point of ethnographic studies, "practice places researchers in the midst of whatever it is they study. From this vantage, researchers can examine various phenomena as perceived by participants and represent these observation accounts" (Berg, 2001:134).

Understanding grounded theory approaches was imperative to this research. However, it was also critical to comprehend the ethical issues that may arise from this type of methodologies. Paoletti (2013) identified some of the ethical issues that are involved when collecting data that involves social interaction, such as interaction data that includes interviewing and observation. Paoletti (2013) states that when conducting ethnographic research, it is difficult to take into account all ethical issues that may arise during the study. Although not an easy task, it is important to inform the participants about the intentions of your study. Depending on the task being conducted, it is important to inform and to obtain consent from the participants in order make them aware of how the data is going to be used (idem).

To conduct this research, three key multi-level marketing companies that have internationalized in Colombia companies from the cosmetics and personal care industry were selected. The three companies are Yanbal (Peru), Amway (United States) and Oriflame (Sweeden). These companies were chosen as they are all in the beauty and personal care industry, MLM multinationals which have had significant sales growth over the last 5 years as it can be observed in Figure 1, and table 2 below.

Table 1: Sales in Retailing by Store-based vs Non-Store: \% Value Growth 2009-2014 in Colombia

\begin{tabular}{lccc}
\hline \% current value growth, retail value rsp excl sales tax & $\mathbf{2 0 1 3 / 1 4}$ & $\begin{array}{c}\mathbf{2 0 0 9 - 1 4} \\
\text { CAGR }\end{array}$ & $\begin{array}{c}\mathbf{2 0 0 9 / 1 4} \\
\text { Total }\end{array}$ \\
\hline Store-based Retailing & 7.8 & 5.7 & 32.0 \\
Non-Store Retailing & 16.1 & 13.7 & 89.7 \\
Retailing & 8.1 & 6.0 & 33.8 \\
\hline
\end{tabular}

Source: Euromonitor International (2015a). 
Figure 1: Companies' earnings from 2009 to 2013

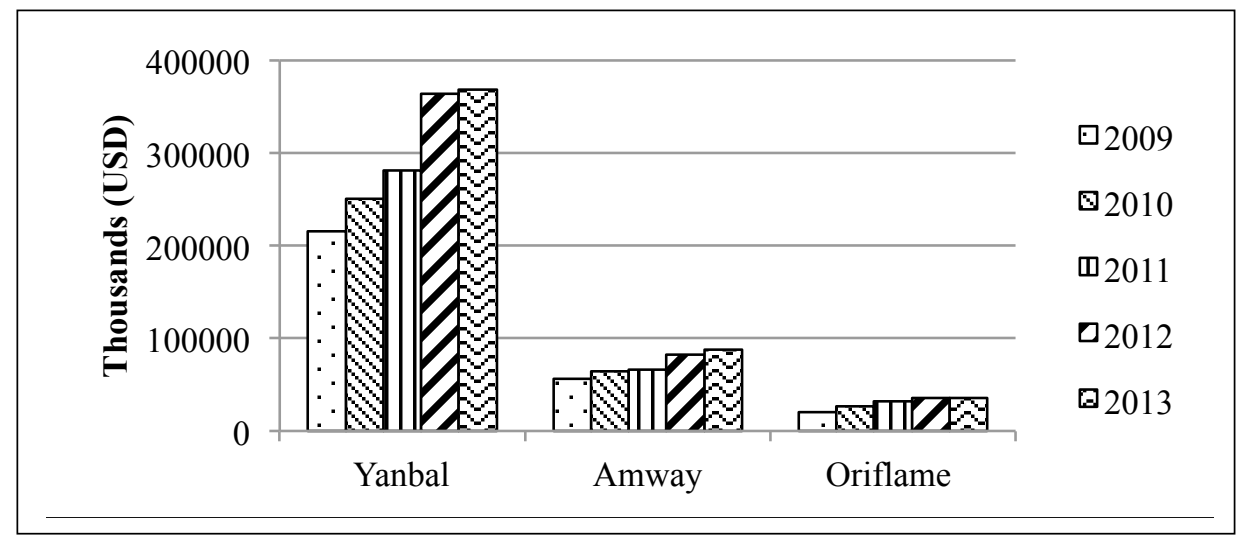

Source: BRP Benchmark

These are the reason for choosing these three particular companies for the present study (see table 1 below for details on their market share in Colombia).

Table 2: Non-Store Retailing Brand Shares in Colombia: \% Value 2011-2014

\begin{tabular}{cccccc}
\hline \% retail value rsp excl sales tax & Company & $\mathbf{2 0 1 1}$ & $\mathbf{2 0 1 2}$ & $\mathbf{2 0 1 3}$ & $\mathbf{2 0 1 4}$ \\
\hline Avon & Avon Colombia Ltda & 23.3 & 19.7 & 15.8 & 13.7 \\
Yanbal & Yanbal de Colombia SA & 7.7 & $\mathbf{8 . 7}$ & $\mathbf{9 . 0}$ & $\mathbf{8 . 7}$ \\
Esika & Belstar SA & 12.5 & 11.1 & 9.0 & 7.9 \\
Amway & Amway Colombia SA & $\mathbf{2 . 9}$ & $\mathbf{2 . 9}$ & $\mathbf{2 . 9}$ & $\mathbf{3 . 0}$ \\
Oriflame & Oriflame de Colombia SA & $\mathbf{1 . 6}$ & $\mathbf{1 . 4}$ & $\mathbf{1 . 3}$ & $\mathbf{1 . 3}$ \\
Other companies & & $\mathbf{5 2}$ & $\mathbf{5 6 , 2}$ & $\mathbf{6 2}$ & $\mathbf{6 5 , 4}$ \\
Total & & $\mathbf{1 0 0 . 0}$ & $\mathbf{1 0 0 . 0}$ & $\mathbf{1 0 0 . 0}$ & $\mathbf{1 0 0 . 0}$ \\
\hline
\end{tabular}

Source: Euromonitor International (2015b)

First, the data was collected through primary (direct observation, unstructured open-ended interviews, structured face-to-face survey, and telephone interview) and secondary sources (corporate websites, and specialized business media).

Second, a 30-day immersion ethnographic study was conducted. This involved participantobservations at meetings, conferences and events organized by MLM leaders to consolidate their network, and recruiting new distributors. The aim of the data collection face was to gain an inside understanding on how do these companies attract and maintain their independent consultants; how are their methods possibly target to the distributors in the marginal labor market; and if international business opportunities are promoted or encourage. The data was intentionally collected aiming to answer if the MLM companies can offered work opportunities for distributors in the targeted country internationalization. 
Some of the questions which guided the interactions with MLM leaders and current distributors were

- What are the requirements to become an independent consultant of your company?

- What is the initial investment or sign-up fees?

- I live in Colombia, but if I decide to move to another country, can I continue working for the company as an independent consultant to the country I move to?

- Given that this is a cosmetics / personal care company; can both men and women work in your company?

- $\quad$ Does my compensation come from my merchandise sales, from sales by the members I recruited, or both?

- What additional benefits do you offer in addition to your compensation plan?

- How do you handle the reporting of income for tax purposes?

- Does the company offer or requires health insurance or contributions to pensions?

The gathered data from was memo written, systematically compared with ongoing reflections, and it was coded, classified, cross-referenced and analyzed. This systematic and thorough approach aimed to develop and test theory from patterns emerging from the obtained data.

\section{FINDINGS AND DISCUSSION}

The information gathered through primary and secondary sources provided significant information about the expansion of Yanbal, Amway and Oriflame to Colombia. The companies' websites and newspaper articles provided information about the year of entry to Colombia. This information was match against other articles describing the economic conditions at the time of entry to the country. The information gathered in the ethnographic study provided the evidence as to if MLM companies provided international income opportunities.

\section{(a) 1979: Yanbal}

Fernando and Eduardo Belmont founded Yanbal in 1967. The brothers came from a family with a tradition in the cosmetics and pharmaceuticals industries in Peru (Pricewaterhouse Coopers, 2004). In 1988, the brothers parted ways and Fernando kept Yanbal while Eduardo went to create what today is Yanbal's competition, Belcorp (Castano, 2012). However, Yanbal started their internationalization process while the brothers were still in the partnership. The internationalization begins with the start of operations in Ecuador in 1977. Then, in 1979, Yanbal entered the Colombian market (Yanbal International, 2015).

Yanbal's focus since its beginnings was to only employ women. This is because the founders wanted to provide employment opportunities to Latin American women who did not have the same employment opportunities as men (conversation with Yanbal representative on October 2, 2014) and who were looking to become economically independent (El Tiempo, 1997). Latin America was experiencing a change in the labor force since the 1950's. Many of the rural employees were moving to the cities looking for better income opportunities. Hence, by the 1970s, there was a surplus of employees in the cities, causing many to perform 
paid activities in the informal economy, especially for women (Portes \& Schauffler, 1993 and De Suremain, 1989); and, it is important to note that women are more susceptible to lack opportunities of formal work and resort to the informal economy (Wilson, 1998 and Rodina et al., 2012). Additionally, key participants of the informal economy are low skilled workers and uneducated women (Losby et al. 2012) and as noted during the participation process (see table 2), Yanbal has no barriers of entry with the exception of legal age requirements and sex. In Ecuador, Yanbal is the leader in its field and their direct sales model has helped its growth through women in the informal economy, allowing them to dictate their work schedules and allowed ease of entry into these companies (Masi di Casanova, 2011a).

Table 3: Companies Earnings from 2009 to 2013

\begin{tabular}{|c|c|c|c|}
\hline & Yanbal & Amway & Oriflame \\
\hline $\begin{array}{l}\text { Requirements to } \\
\text { join }\end{array}$ & $\begin{array}{l}\text { Be over } 18 \text { of age, } \\
\text { copy of Colombian } \\
\text { Identification Card } \\
\text { (Cedula) and credit } \\
\text { check. }\end{array}$ & $\begin{array}{l}\text { Be over } 18 \text { years of } \\
\text { age and copy of } \\
\text { Colombian } \\
\text { Identification Card } \\
\text { (Cedula). }\end{array}$ & $\begin{array}{l}\text { Be over } 18 \text { years of } \\
\text { age, copy of } \\
\text { Colombian } \\
\text { Identification Card } \\
\text { (Cedula) and provide } \\
\text { utilities invoice as } \\
\text { proof of residence. }\end{array}$ \\
\hline $\begin{array}{l}\text { Initial investment / } \\
\text { Sign-up fees }\end{array}$ & $\begin{array}{l}\$ 30,000 \text { COP (about } \\
\$ 15 \text { USD) purchase } \\
\text { in Yanbal products. }\end{array}$ & $\$ 30$ USD & $\begin{array}{l}\$ 19,000 \text { COP (about } \\
\$ 10 \text { USD). }\end{array}$ \\
\hline $\begin{array}{l}\text { Opportunity to } \\
\text { work in another } \\
\text { country }\end{array}$ & $\begin{array}{l}\text { No, only in } \\
\text { Colombia (or } \\
\text { country where } \\
\text { subscription is } \\
\text { done). }\end{array}$ & $\begin{array}{l}\text { Yes, with the same } \\
\text { membership from } \\
\text { Colombia you can } \\
\text { work in } 12 \\
\text { countries in } \\
\text { Central and South } \\
\text { America. }\end{array}$ & $\begin{array}{l}\text { With the same } \\
\text { membership from } \\
\text { Colombia, you can sell } \\
\text { and recruit new } \\
\text { members for your } \\
\text { network in all the } \\
\text { countries where the } \\
\text { company operates. }\end{array}$ \\
\hline Gender biased & $\begin{array}{l}\text { Yes, only females } \\
\text { can work for the } \\
\text { company. Husbands } \\
\text { and sons of women } \\
\text { who have reached } \\
\text { level of director can } \\
\text { apply to join under } \\
\text { Director's network. }\end{array}$ & $\begin{array}{l}\text { No, both men and } \\
\text { women can join. }\end{array}$ & $\begin{array}{l}\text { No, both men and } \\
\text { women can join. }\end{array}$ \\
\hline $\begin{array}{l}\text { Compensation } \\
\text { come from } \\
\text { payment plan or } \\
\text { sales from } \\
\text { members recruited }\end{array}$ & Both & Both & Both \\
\hline
\end{tabular}




\begin{tabular}{llll}
\hline $\begin{array}{l}\text { Additional benefits } \\
\text { to compensation } \\
\text { plan }\end{array}$ & $\begin{array}{l}\text { International trips } \\
\text { and vehicle for } \\
\text { higher bracket } \\
\text { members. Free } \\
\text { products and prizes. }\end{array}$ & $\begin{array}{l}\text { Training seminars } \\
\text { ranging from } \\
\text { financial topics to } \\
\text { leadership. Annual } \\
\text { international trips } \\
\text { for top members. }\end{array}$ & $\begin{array}{l}\text { Product gifts from the } \\
\text { company, international } \\
\text { trips and 25\% discount } \\
\text { in all company product } \\
\text { purchases. }\end{array}$ \\
\hline Tax reporting & $\begin{array}{l}\text { The company } \\
\text { withholds taxes: } \\
\text { however, members } \\
\text { are responsible for } \\
\text { filing taxes if they } \\
\text { need to under } \\
\text { Colombia law. }\end{array}$ & $\begin{array}{l}\text { The company } \\
\text { withholds taxes: } \\
\text { are responsible for } \\
\text { filing taxes if they } \\
\text { need to under } \\
\text { Colombia law. }\end{array}$ & $\begin{array}{l}\text { The company } \\
\text { withholds taxes: } \\
\text { however, members are } \\
\text { responsible for filing } \\
\text { tanes they need to }\end{array}$ \\
$\begin{array}{l}\text { Company offers or } \\
\text { requires health } \\
\text { insurance or } \\
\text { contributions to } \\
\text { pensions }\end{array}$ & Neither & Neither \\
\hline
\end{tabular}

Source: Information gathered through participant observation.

\section{(b) 1996 - Amway and 1997 - Oriflame}

Amway was founded in 1959 by Rich DeVos and Jay Van Andel. Soon after the founding of the company, the partners internationalized the company by expanding their operations to Canada in 1962. It is possible that the company internationalized to Canada first using a sequential model (Cuervo-Cazurra, 2011). Then, as they gathered experience at home and in markets similar to theirs, the following decade they expanded to 8 additional international markets. This step consolidated Amway's international presence as today they are one of the leading MLM companies in the world, operating in over 80 countries and territories worldwide (Amway, 2013). In 1967, while Amway was developing their operations internationally, Oriflame was starting their operations in Sweden. The company, founded by two brothers and a friend, rapidly expanded their international operations by starting business in neighboring countries in 1968. It took almost two decades to leave the European continent by internationalizing to Indonesia in 1986 and finally opening their business in Colombia in 1997. Today, they operate in over 60 countries worldwide (Oriflame, 2012).

When Amway entered the Colombia in 1996 (Gaviria, 1996), the country was entering the worst recession in decades (Rowland, 2005). This recession spiked unemployment levels up to $20 \%$ in the late $1990 \mathrm{~s}$. The rise of unemployment has a direct impact on the rise of informal jobs. Mondragón, Peña \& Wills (2010) support this patterns by determining that in Colombia the levels of informality are positively correlated with unemployment. Given the conditions of the Colombian economy starting 1996, it is unlikely to believe that a foreign multinational would enter the Colombian market. Addionally, Oriflame followed suit in 1997. 
However, given their business models of expansion through MLM, and almost no requirements to join their ranks (see table 2), Colombia could have been the perfect setting at the time. This was even acknowledged by the local newspapers as it stated that 1996, the year that Amway entered the Colombian market could be the year of the direct sales boom due to the rise of the "rebusque", which a Colombian slang word for flexible arrangement and informal work in Colombia (Gaviria, 1996)

\section{(c) International Income Opportunity for MLM sales representatives}

In today's globalization, conducting business in other countries is more possible than ever. MLMs are starting to understand this by providing international working opportunities to their members. During the ethnographic study, part of it was to participate as a Colombian citizen looking to join a MLM company and see if the same membership obtained in Colombia would allow working in other countries. It was determined that 2 out of 3 of the companies analyzed, Amway and Oriflame, provided this international opportunity (see table 2). Yanbal, according to its representative, was in the process of implementing this international model. While gathering information about joining Oriflame, the consultant stated that this was very important because there is a lot of work placed into building a successful network. If a representative decides to move to another country it is important to continue receiving an income from the network left behind and the new members recruited in the new country of residence.

One of the most evident keys to success in the MLM industry is the use of the independent distributor's business network. During the events, the members of the company's would spend significant time to developing the network and in the meetings, top members would encourage members to tap into their work and family relationships to increase the possibility of income generation. Furthermore, in monthly conferences the guest speakers and special guest would be from other places, such as the United States or countries in the Caribbean. Many took advantage of these settings to establish social relationships and support groups with these members to increase value in their network, as stated by Holm, Eriksson \& Johanson (1999), and can possibly use this network contact to possibly expand their work to international regions, if they so desire, in a successful manner (Vasilchenko \& Morrish, 2011).

\section{(d) MLM and size of the in informal sector Latin America}

It was found that the studied MLM companies or sales representatives of these do not make contributions to the tax system or social security for their distributors (health insurance or mandatory pensions). It was found in this study that when companies' representatives are asked about tax reporting, they claimed that they paid taxes from their revenue; however, it is up to the independent representative to report earnings to the tax reporting agencies (see table 2). Furthermore, many of the independent consultants have increased domestic economic informality the sector further by having other people, usually family and friends non-affiliated to the company, selling on their behalf for a smaller share of the earnings. As it was claimed by a Yanbal consultant, this helps the affiliated representative focus on network growth while maintaining the required quota of sales. 
The foreign entry mode of the studied to Colombia, coincides with periods of formal labour market contraction. This might indicate MLMs target the unemployed and income deprived population, both domestically and internationally. As noticed, Amway and Oriflame entered the Colombian market during a strong recession. Many of these firms may use business cycles and unemployment to enter international markets. Given the employment needs at a time of economic crises and the correlation between unemployment and the size of the informal economy, these companies provide employment opportunities to people who do not have easy access to formal employment. As Cahn (2008: 430) states, "becoming a direct seller requires no previous experience, no formal education, and little startup capital, so it is particularly attractive when other forms of employment are scarce". During the attended Amway motivational seminars there was a direct and strong message from the top leadership about pushing for the recruitment of those in financial need. Many of the characteristics mentioned about the people to pursue were targeted to members in the informal economy: people working from home, those who currently supplement their day job income through resells of merchandise and those who are currently unemployed and looking for an employment opportunity.

In a conversation with a Yanbal female representative (October 2, 2014), she mentioned that when she entered the business over 10 years ago, she became unemployed and was selling food from her home while looking for a new job. A friend approached her to sell Yanbal as an alternative to her home food selling and suggested that instead to use that time towards building her network. It is apparent that she was given a pitch based on her informal work; however, this situation sparks interest as she decided to join Yanbal more out of a sense of belonging to a company. As time progressed, she decided to make a career as an independent consultant because Yanbal made her feel as an integral part of the growth of the firm. She enjoyed the meetings with her peers and working with the members she recruited. Stewart, Courtright, \& Barrick (2012) found that for people that care about the people they work with, sense of belonging motivates them more to work than money. Additionally, the researchers found that peer pressure plays a role in this and workers do not want to disappoint their peers; hence, the motivation of pleasing the other is more powerful than the earnings. When the Yanbal representative was asked about her decision to stay as an independent representative, she stated that it was because she found a family in the company and did not want to disappoint her "Director" (title given to Yanbal's top earners) as she had dedicated a lot of time supporting her growth in the company.

Developing and emerging countries can experience unstable employment due to unstable economies. Unemployment, especially for the low-skilled and uneducated workers, and low salaries for skilled workers cause labor migration (Dayton, Pfeiffer, Schuettler, \& Schwinn, 2009). In the presented study, it was presented that MLM companies can provide an opportunity to develop opportunities for international business. During an Amway seminar (May, 2014), the guest speaker was a Colombia medical doctor who was practicing medicine, but getting paid low wages for his work. After being presented with an opportunity to move to Canada to practice medicine in this country, he joined Amway in Colombia to work as independent consultant in Canada while he legally validated his qualifications to practice medicine in his new country. His pitch was to promote the development of networks outside of the home country, while continuing to earn money from the home network. This international expansion 
of individuals working as independent consultants in MLMs, helps the internationalization of the companies tremendously as they use their networks to expand the name of the business in international markets. Gomez (2014) stated that there is a consensus in regards to the importance of networks in the internationalization of firm. For this reason, MLMs impendent consultants who expand their networks to foreign countries can take advantage of the international business opportunities and become the key network that further the MLM internationalization.

\section{CONCLUSION \& LIMITATIONS}

It is possible that multi-level and direct sales companies internationalize using their social and family networks in Latin America and the Caribbean. From the empirical research, using Colombia as the setting for the study, it was observed that Yanbal internationalized by targeting women who lacked employment opportunities the chance to work and be independent. Additionally, Amway and Oriflame entered the Colombian market when the domestic economy was going through a recession. It seems unlikely that a company would enter a country during economic instability; however, recessions raise unemployment and it was witnessed that as unemployment rises, the size of the informal economy increases. For this reason, it is possible that these MLM increased their international presence in Colombia in that specific timeframe to expand and consolidate their network through those who lack or lost their formal employment.

Several MLM companies provide international employment opportunities by allowing their independent consultants to work in other countries where they operate, without losing income from their home network and being able to earn from new affiliates in the foreign host country. Yet, MLM companies do not provide formal employment opportunities, as MLM do not provide social security benefits and although they withhold taxes from independent consultants, if earnings are over the required amount to file taxes (as in the case of Colombia), their total earnings can go unreported to the required reporting agencies. Additionally, many of their representatives contribute to the expansion of the informal economy by hiring others (not affiliated to the company) to conduct direct sales for them while they focus on both the domestic and international expansion of their network. An interesting point is that considering that many of the sales pitches given by the MLM representatives seem to be targeted to those in the informal sector, most of the people encountered in these events are people who work in MLM to compliment the earnings from their formal employment. This may be because people usually build their work around those closest to them: family, friends and co-workers. This constant task and necessity of increasing their business network to generate more income may contribute to business network theory as it evidence shows the need of this socially constructed business relationships to have a successful MLM program.

This study presented some limitations. The ethnographic study involving participant observation was significantly short to retrieve significant data to compile and analyze. In many cases, ethnographic studies take years and this study consisted of 30 day immersion. Additionally, the short amount of time also presented difficulties in establishing trust between the researcher and participants of the MLM companies. Many were skeptical in engaging in conversations when they were informed of the purpose of the discussions. Lastly, only one country was used in the study and it may not be a representative sample for all Latin 
American countries. Nevertheless, this research also provides a theoretical contribution to the internationalization theory, specifically the business network theory, as it offers an understanding on business can take advantages to expand to countries with a large bottom of the pyramid (BOP). A process of international market expansion in a specific country can also be successfully focused on the BOP, as it develops both income and consumption. This dual role of been income and consumption provider enhances brand appreciation; and could accelerate the internationalization of company via direct sales representatives.

\section{REFERENCES}

Albaum, G., \& Peterson, R. A. (2011). Multilevel (network) marketing: An objective view. Marketing Review, 11(4), 347-361. doi: http://dx.doi.org/10.1362/14693471 $1 \mathrm{X} 13210328715902$

Amway Host. (2014, August 24). Comment made during Amway Seminar. Medellin, Colombia.

Amway. (2013). History Timeline. Retrieved from http://www.amway.com/about-amway/our company/heritage/history-timeline

Anderson, K., Fields, N., Harootyan, R., \& Richardson, V. (2013). Inclusion or exclusion? Exploring barriers to employment for low-income older adults. Journal of Gerontological Social Work, 56(4), 318-334. doi: 10.1080/01634372.2013.777006

Berg, B. L. (2001). Ethnographic Field Strategies. In B. L. Berg (Eds.), Qualitative research methods for the social sciences (4th ed., pp. 133-177). Needham, MA: Allyn and Bacon.

Bloch, B. (1996). Multilevel marketing: what's the catch? Journal of Consumer Marketing, 13(4), 18-26. doi: http://dx.doi.org/10.1108/07363769610124519

Bosley, S., \& McKeage, K. K. (2015). Multilevel Marketing Diffusion and the Risk of Pyramid Scheme Activity: The Case of Fortune Hi-Tech Marketing in Montana. Journal of Public Policy and Marketing, 34(1), 84-102. doi: http://dx.doi.org/10.1509/jppm.13.086

Bremmer, I. (2015, January 22). The new world of business. Fortune. Retrieved from http:// fortune.com/2015/01/22/the-new-world-of-business/

Cahn, P. S. (2008). Consuming class: Multilevel marketers in neoliberal Mexico. Cultural Anthropology, 23(3), 429-452. doi: 10.1525/can.2008.23.3.429

Castano, I. (2012, Novemeber 02). Peru's feuding beauty brothers join forbes' billionaire ranks. Retrieved from http://www.forbes.com/sites/ivancastano/2012/11/02/perusfeuding-beauty-brothers-join-forbes-billionaire-ranks/

Castrejon, R. (2014). Las 20 mejores compañías de venta directa, listado del 2014. Retrieved from http://www.businessreviewamericalatina.com/leadership/1194/Las-20-mejorescompañías-de-venta-directa-listado-del-2014 
Choudhary, R., \& Kamal, H. (2013). Multi-level marketing (MLM) for socio-economic development. International Journal of Reviews, Surveys and Research, 2(1), 45-55.

Coughlan, A. T., \& Grayson, K. (1998). Network marketing organizations: Compensation plans, retail network growth, and profitability. International Journal of Research in Marketing, 15(5), 401-426. doi: 10.1016/S0167-8116(98)00014-7

Coviello, N. E. (2006). The network dynamics of international new ventures. Journal of International Business Studies, 37(5), 713-731. doi: 10.1057/palgrave.jibs.8400219

Croft, R., \& Woodruffe, H. (1996) Network Marketing: The Ultimate in International Distribution? Journal of Marketing Management, 12(1-3), 201-214. doi: 10.1080/0267257X.1996.9964409

Cuervo-Cazurra, A. (2011). Selecting the country in which to start internationalization: The non-sequential internationalization model. Journal of World Business, 46(4), 426-437. doi: $10.1108 / 02651339010137414$

Dai, F., Wang, K. Y., \& Teo, S. T. T. (2011). Chinese immigrants in network marketing business in Western host country context. International Business Review, 20(6), 659-669. doi:10.1016/j.ibusrev.2011.02.015

Dayton-Johnson, J., Pfeiffer, A., Schuettler, K., \& Schwinn, J. (2009). Migration and Employment. In Promoting pro-poor growth employment (pp. 149-177). OECD.

De Suremain, M. D. (1989). Women's involvement in the informal urban economy - Colombia. United Nations Educational, Scientific and Cultural Organization. Columbia: Division of Studies for Development, Unesco.

Doz, Y. (2011). Qualitative research for international business. Journal of International Business Studies, 42(5), 582-590. doi: 10.1057/jibs.2011.18

Draper, E. (1985). Women's work and development in Latin America. Studies in Comparative International Development, 20(1), 3-30. doi: 10.1007/BF02718316

El Tiempo (1997). La Belleza con proyección. (November 1). Retrieved from http://www. eltiempo.com/archivo/documento/MAM-661385

Euromonitor International (2015a). Retailing in Colombia: Industry Overview. Retrieved from Euromonitor Passport GMID database.

Euromonitor International. (2014a). Beauty in Latin America: A Revolution of Expectations. Japan: Euromonitor International.

Euromonitor International. (2014b). Direct Selling in Colombia. Retrieved from Euromonitor Passport GMID database.

Euromonitor International. (2015b). Beauty and Personal Care in Colombia: Industry Overview. Retrieved from Euromonitor Passport GMID database. 
Feinberg, R.A., \& Eastlick, M. A (1997). Direct Marketing in the USA: Past Failures and Future Promises. International Journal of Retail \& Distribution Management, 5(8), 256261.

Gaviria, A. (1996, September 15). Ventas, directo a su bolsillo. El Tiempo. Retrieved from http:/www.eltiempo.com/archivo/documento/MAM-501296

Gonzalez-Perez, M. A., \& Velez-Ocampo, J. F. (2014). Targeting their own region: Internationalisation trends of Colombian multinational companies. European Business Review, 26(6), 531-555. doi: http://dx.doi.org/10.1108/EBR-03-2013-0056

Gordon, L. (November 24, 2010). Colombia mirrors solid beauty industry growth seen elsewhere in Latin America. Euromonitor International.

Henkel, J., \& Block, J. (2013). Peer influence in network markets: A theoretical and empirical analysis. Journal of Evolutionary Economics, 23(5), 925-953. doi: 10.1007/s00191-0120302-4

Hill, S., Foster, P., \& Volinsky, C. (2006). Network-based marketing: Identifying likely adopters via consumer networks. Statistical Science, 21(2), 256-276. doi: $10.1214 / 088342306000000222$

Holm, D. B., Eriksson, K., \& Johanson, J. (1996). Business networks and cooperation in international business relationships. Journal of International Business Studies, 27(5), 1033-1053. doi: 10.1057/palgrave.jibs.8490162

Holm, D. B., Eriksson, K., \& Johanson, J. (1999). Creating value through mutual commitment to business network relationships. Strategic Management Journal, 20(5), 467-486. doi: 10.1002/(SICI)1097-0266(199905)20:5<467::AID-SMJ38>3.0.CO;2-J

Iacono, J., Brown, A., \& Holtham, C. (2009). Research Methods - a Case Example of Participant Observation. Electronic Journal of Business Research Methods, 7(1), 39-46.

Johanson, J., \& Vahlne, J-E. (2009). The Uppsala internationalization process model revisited: from liability of foreignness to liability of outsidership, Journal of International Business Studies, 40(9), 1411-1431.

Koehn, D. (2001). Ethical issues connected with multi-level marketing schemes. Journal of Business Ethics, 29(1-2), 153-160. doi: 10.1023/A:1006463430130

Lahiri, I., \& Das, M. K. (2012). MLM vs Non-MLM brands: Attitudinal evaluation through customers' eye. International Journal of Business Insights \& Transformations, 5(2), 6975.

Liesch, P. W., Welch, L. S., \& Buckley, P. J. (2011). Risk and Uncertainty in Internationalisation and International Entrepreneurship Studies. Management International Review, 51(6), 851-873.

Losby, J. L., Edgecomb, E. L, Else, J. F., Kao, V., Kingslow, M. E., \& Malm, E. T. (2012). Informal economy literature review. Newark, DE: ISED Consulting and Research. 
Markovic, M. (2009). Globalization and gender participation in the informal sector in developing and transitional countries. E M Ekonomie A Management, 12(4), 17-26.

Masi de Casanova, E. (2011a). Making up the difference: Women, beauty, and direct selling in Ecuador (pp. 14-16). Austin: University of Texas Press. doi: 10.1111/j.19354940.2012.01202.x

Masi de Casanova, E. (2011b). Multiplying themselves: Women cosmetics sellers in Ecuador. Feminist Economics, 17(2), 1-29. doi: 10.1080/13545701.2011.568419.

Mason, K., Chakbrabarti, R., \& Singh, R. (2013) What are bottom of the pyramid markets and why do they matter? Marketing Theory, 13(3), 401-404. doi: 10.1177/1470593113489193

Mondragón-Vélez, C., Peña, X., \& Wills, D. (2010). Labor market rigidities and informality in Colombia. Economia, 11(1), 65-101.

Nga, J. K. H., \& Mun, S. W. (2011). The influence of MLM companies and agent attributes on the willingness to undertake multilevel marketing as a career option among youth. Journal of Research in Interactive Marketing, 5(1), 50-70. doi: http://dx.doi. org/10.1108/17505931111121525

Oriflame. (2012, January 1). Fact Sheet. Sweden: Oriflame.

Paoletti, I. (2013). Ethics and the Social Dimension of Research Activities. Human Studies, 37(2), 257-277. doi:10.1007/s10746-013-9299-4

Peterson, R., \& Albaum, G. (2007). On the ethicality of internal consumption in multilevel marketing. Journal of Personal Selling \& Sales Management, 27(4), 317-323. doi: 10.2753/PSS0885-3134270403

Portes, A., \& Schauffler, R. (1993). Competing Perspectives on the Latin American Informal Sector. Population and Development Review, 19(1), 33-60. doi: 10.2307/2938384

Pratt, M. (2000). The good, the bad, and the ambivalent: Managing identification among Amway distributors. Administrative Science Quarterly, 45(3), 456-493. doi: 10.2307/2667106

Pratt, M., \& Rosa, J. (2003). Transforming work-family conflict into commitment in network marketing organizations. Academy of Management Journal, 46(4), 395-418 doi: $10.2307 / 30040635$

Pricewaterhouse Coopers. (2004). 7th South American edition of the annual global CEO survey. Retrieved from http://www.pwc.com.uy/en/encuesta-ceo/assets/pe-fernandobelmont.pdf

Rowland, P. (2005). Foreign and domestic firms in Colombia: Development and trends 19962003. Columbia: Banco De La República, Borradores de economía.

Scott, L., Dolan, C., Johnstone-Louis, M., Sugden, K., \& Wu, M. (2012). Enterprise and inequality: A study of Avon in South Africa. Entrepreneurship Theory and Practice, 36(3). doi: 10.1111/j.1540-6520.2012.00507.x 
Stewart, G. L., Courtright, S. H., \& Barrick, M. R. (2012). Peer-based control in self-managing teams: Linking rational and normative influence with individual and group performance. Journal of Applied Psychology, 97(2), 435-447. doi: 10.1037/a0025303

Strauss, A., \& Corbin, J. (1994). Basics of qualitative research. Thousand Oaks, Sage Publications.

Strauss, A., \& Corbin, J. (1998). Grounded Theory Methodology. In N. K. Denzin \& Y. S. Lincoln (Eds.), Handbook of Qualitative Research (pp. 217-285). Thousand Oaks: Sage Publications.

The World Federation of Direct Selling Associations (WFDSA). (2012). Global sales and direct selling community - 2012. Washington. Retrieved from http://www.wfdsa.org/files/ pdf/global-stats/Sales_and_Community_2012.pdf

The World Federation of Direct Selling Associations (WFDSA). (2013). Global direct selling - 2013 retail sales. Washington. Retrieved from http:/www.wfdsa.org/files/pdf/globalstats/Sales_Report_2013.pdf

Tortora, A. (2014). Billion Dollar Markets. Direct selling news. Retrieved from http:// directsellingnews.com/index.php/view/billion_dollar_markets\#.Vfjq5BFViko

Vander, P., \& Keep, W. (2002). Marketing fraud: An approach for differentiating multilevel marketing from pyramid schemes. Journal of Public Policy \& Marketing, 21(1), 139-151. doi: http://dx.doi.org/10.1509/jppm.21.1.139.17603

Vasilchenko, E., \& Morrish, S. (2011). The role of entrepreneurial networks in the exploration and exploitation of internationalization opportunities by information and communication technology firms. Journal of International Marketing, 19(4), 88-105. doi: http://dx.doi. org/10.1509/jim.10.0134

Wilson, A. (1999). The empire of direct sales and the making of Thai entrepreneurs. Critique of Anthropology, 19(4), 401-422. doi: 10.1177/0308275X9901900406

Wilson, T. (1998). Approaches to Understanding the Position of Women Workers in the informal sector. Latin American Perspectives, 25(2), 105-119.

Yanbal International (2015.). Historia de Yanbal. Retrieved from http://www.yanbal.com/ colombia/conocenos/historia 